\title{
TANGGUNG JAWAB RUMAH SAKIT MITRA KELUARGA KALI DERES ATAS TINDAKAN PENOLAKAN PASIEN YANG BERUJUNG PADA KEMATIAN DITINJAU DARI UNDANG-UNDANG NO.8 TAHUN 1999 TENTANG PERLINDUNGAN KONSUMEN.
}

\author{
Andre Scondery \\ (Mahasiswa Program S1 Fakultas Hukum Universitas Tarumanagara.) \\ (E-mail: scondery09@gmail.com)
}

Dr. Ermanto Fahamsyah S.H., M.H

(Corresponding Author)

(Dosen Hukum Perlindungan Konsumen dan Hukum Acara PenyelesaianSengketa konsumen

Fakultas Hukum Universitas Tarumanagara, Meraih SarjanaHukum dari Fakultas Hukum

Universitas Jember, Magister Hukum Ekonomi dari Universitas Indonesia dan Doktor Ilmu

Hukum (Ekonomi) dari Universitas Indonesia.)

(E-mail: ermanto_fahamsyah@yahoo.co.id,ermantofahamsyah@gmail.com)

\begin{abstract}
The hospital is a place where a person receives health services, where the hospital is a place that does not discriminate against a person in providing health services and this has been regulated by the Hospital Law, Health Act and also the Consumer Protection Act. But in reality there are still those who perform service actions by distinguishing the case of a Deborah baby who received a different treatment by the hospital so that the baby Deborah patient died of the treatment given by the hospital. The treatment is in the form of a hospital that does not carry out social functions based on the applicable law so that this action results in death to patients. This is caused because the family of Deborous patients cannot follow the request of the hospital which requires patients to pay the amount set by the house sick so that the hospital does not carry out actions according to social functions. In this case the hospital must be responsible for the actions it has taken.
\end{abstract}

Keywords: Consumer Protection, Hospital Responsibility 


\section{PENDAHULUAN}

\section{A. Latar Belakang}

Indonesia adalah suatu negara yang menjunjung tinggi nilai keadilan di dalam negaranya. Semuanya diatur oleh undang-undang yang berlaku di negara tersebut. Warga negaranya semua diperlakukan adil dan tidak dibeda-bedakan, hal ini sudah diatur dalam Undang-undang Dasar Negara Republik Indonesia Tahun 1945 (yang selanjutnya di sebut UUD) . Tidak ada unsur diskriminasi di dalam Perundang-undangannya, dan dalam mengenai pelayanan kesehatan untuk masyarakatnya saja sudah diatur oleh undang-undang yang berlaku. Pelayanan kesehatan di Indonesia dalam hal pelaksanaannya semua diatur berdasarkan UUD, di dalam undang-undang tersebut terdapat pasal di dalamnya yaitu pasal $28 \mathrm{H}$ mengenai Hak Asasi Manusia.

Berikutnya pasal 34 UUD mengatur tentang pelayanan kesehatan untuk masyarakat. Selanjutnya dalam pasal 28I ayat 4 UUD dalam undangundang ini mengatur mengenai hak-hak yang di miliki oleh manusia dalam suatu Negara, maka dari itu Negara dalam pasal ini bertanggung jawab dalam menangani hak yang di miliki oleh warga negaranya. Semua orang juga memiliki hak asasi manusia yaitu manusia mempunyai hak yang sama dan tidak ada yang dibeda-bedakan, dan dalam pasal tersebut sangat penting digunakan dalam lingkup yang bersangkutan dengan medis. Seperti rumah sakit dan tim ahli medis dapat menggunakan pasal tersebut.

Rumah sakit menggunakan pasal tersebut karena rumah sakit adalah salah satu tempat dimana seseorang mendapatkan pelayanan kesehatan dalam rumah sakit sendiri rumah sakit memiliki fungsi sosial yang artinya rumah sakit tersebut memang fungsinya untuk melayani masyarakat. Selain memberi pelayanan kesehatan rumah sakit ini juga merupakan suatu kebutuhan yang utama bagi masyarakat, karena dengan adanya rumah sakit masyarakat dapat mendapatkan pelayanan kesehatan yang seharusnya bisa di gunakan oleh semua orang jadi rumah sakit adalah suatu kebutuhan yang memang sangat penting yang harus di miliki oleh masyarakat, dan 
fasilitas rumah sakit sangat berperan pada pelayanan di rumah sakit dari segi utama, yaitu sebagai berikut. ${ }^{1)}$ Keamanan pasien, pasien aman dari hal yang membahayakan, seperti kebakaran dan jatuh, ${ }^{2)}$ Keselamatan pasien, dari segi selamat dari fasilitas yang tidak memenuhi standar dan infeksi nosocomial, Kepuasan pasien, dari segi kenyamanan dan kemudahan.

Dalam bangunan rumah sakit semua itu harus dalam ke adaan steril karena rumah sakit baik fasilitas maupun pelayanan yang di berikan kepada rumah sakit terhadap pasien harus di berikan dalam keadaan sangat baik. Pada awalnya rumah sakit didirikan untuk melakukan tugas keagamaan. Maka dari itu, rumah sakit didirikan untuk tujuan fungsi sosial kemanusiaan sesuai dengan apa yang agama perintahkan. Dalam hal ini rumah sakit tujuannya hanya untuk memberi pertolongan kepada masyarakat, khususnya masyarakat yang kurang mampu dalam hal perekonomiannya, oleh karena itu dapat dikenal adanya doctrine of charitable immunity yaitu rumah sakit adalah suatu lembaga karitas. Artinya rumah sakit harus memiliki dan menerapkan nilai-nilai sosial, kemanusiaan dan tidak mencari keuntungan di dalamnya.

Dalam suatu perkembangan doctrine of charitable immunity, rumah sakit pada waktu itu jika terdapat kesalahan dalam pelaksanaannya maka keluarga pasien yang bersangkutan tidak bisa mengugat rumah sakit tersebut. Karena rumah sakit dalam hal ini melakukan tugas sosial kemanusiaan, karena itu rumah sakit tidak dibebani tanggung jawab hukum jika terjadi suatu hal yang bermasalah pada diri pasien yang disebabkan oleh tindakan pelayanan medis yang salah di rumah sakit. Dengan kata lain, dikarenakan tugas rumah sakit lebih menekankan pada pelayanan fungsi sosial, maka tidak dimungkinkan untuk menggugat rumah sakit. ${ }^{3)}$

Rumah sakit merupakan sebuah tempat untuk menyediakan pelayanan kesehatan dan menyelenggarakan upaya kesehatan dan juga dalam hal ini

\footnotetext{
1) Boy Subirosa Sabarguna, Bangunan Rumah Sakit. (Jakarta: Salemba Medika, 2011), hal. 2.

${ }^{2)}$ Ibid., hal. 2.

3) Azrul Azwar, Pengantar Administrasi Kesehatan, (Jakarta: Binarupa Aksara, 2004), hal.
} 66. 
yang bersifat penyembuhan dan pemulihan pasien dan keselamatan pasien. Pelayanan kesehatan diberikan oleh pihak rumah sakit kepada pasien dapat juga dipandang sebagai pelayanan yang diberikan antara pelaku usaha (Rumah Sakit) dengan pasien (Konsumen). ${ }^{4)}$ Penilaian konsumen terhadap kualitas pelayanan rumah sakit merupakan suatu hal terpenting sebagai acuan dalam memberikan pelayanan sehingga terciptanya sebuah kepuasan pelangan juga membuat suatu loyalitas dari konsumen. ${ }^{5)}$

Sekarang ini dalam hal penyelenggaraan memberikan suatu pelayanan kesehatan di rumah sakit tidak seperti pada zaman dahulu. Karena kebutuhan untukmengurus rumah sakit dengan berbagai modal tidak bisa lagi dielakkan. Rumah sakit membutuhkan modal yang cukup terutama dengan memperbanyak teknologi yang cangih dan juga baru yang harus disediakan oleh rumah sakit. Tenaga yang cukup banyak bisa juga menjadi kebutuhan yang utama dalam rumah sakit sehingga membutuhkan pengorganisasian yang lebih professional dan tersedianya pekerja di bidang teknis yang handal untuk mengoprasikan alat-alat yang semakin canggih. Oleh sebab itu, dalam hal ini mau tidak mau akan mempengaruhi fungsi rumah sakit dalam menyelengarakan pelayanan kesehatan.

Pada zaman sekarang ini rumah sakit memiliki karakteristik dan organisasi yang kompleks dan juga paradigma yang sudah berubah tidak seperti dahulu. Rumah sakit saat ini tidak lagi dianggap kebal terhadap segala macam bentuk gugatan hukum yang di berikan oleh pasien, yang sebelumnya rumah sakit dianggap sebagai lembaga sosial kebal hukum. Dalam hal ini berdasarkan doctrine of charitable immunity. Perubahan paradigma tersebut terjadi sejak kasus Darling vs Charleston Community Memorial Hospital (1965), ${ }^{6}$ ) manajemen modern, lengkap dengan manajemen risiko.

\footnotetext{
4) Indra Bastian, Penyelesaian Sengketa Kesehatan, (Jakarta: Salemba Medika, 2011), hal. 5.

5) Tjiptono dan Chandra, Pemasaran Jasa. (Yogyakarta: Bayu Media Publishing, 2005), hal. 28.

6) Sofwan Dahlan, Malpraktik dan Tanggung Jawab Korporasi. (Bali: Kongres Nusa Dua Bali, 2014), hal. 1.
} 
Selain itu pada saat ini rumah sakit terlihat adanya macam-macam pekerja yang ahli kesehatan dengan ilmu yang di miliki masing-masing berinteraksi satu dengan yang lain. Dengan kata lain dalam suatu rumah sakit disebut sebagai padat Sumber Daya Manusia (SDM) dan padat ilmu pengetahuan dan teknologi. Ilmu pengetahuan dan teknologi dibidang kesehatan, saat ini sedang sangat berkembang sekali hal ini di karenakan agar semakin maju tenaga kesehatan yang di miliki oleh rumah sakit guna menuju pada keselamatan pasien (patient safety).

Perkembangan yang sangat berpengaruh terhadap fungsi dan peran rumah sakit saat ini, menurut Endang Wahyati Yustina, ${ }^{7)}$ adalah bahwa rumah sakit mempertemukan tugas yang prinsipil yang membuat berbeda dengan institusi lain yang melakukan kegiatan pelayanan jasa. Pertama, rumah sakit merupakan institusi yang mempertemukan tugas yang didasari oleh dalil-dalil etik medik, karena merupakan tempat bekerjanya para professional di bidang medik. Kedua, rumah sakit bertindak sebagai institusi yang bergerak dalam hubungan-hubungan hukum

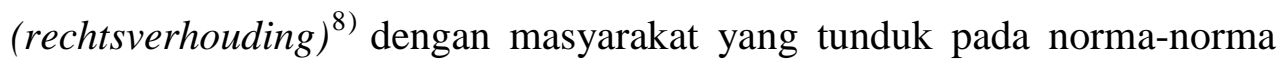
dan etika masyarakat.

Seterusnya yang dimaksud dengan fasilitas pelayanan kesehatan adalah di mana suatu alat juga atau tempat yang dipakai untuk menyelenggarakan suatu pelayanan kesehatan, baik dalam promotif, preventif, kuratif dan maupun rehabilitatif yang juga dilakukan oleh pemerintah, pemerintah daerah, atau masyarakat Pasal 1 Angka 7 Undang-undang No 36 Tahun 2009 tentang Kesehatan. Secara eksplisit salah satu fasilitas pelayanan kesehatan adalah rumah sakit. Hal ini sebagaimana dirumuskan dalam Pasal 1 Angka 1 Undang-undang Nomor 44 Tahun 2009 tentang Rumah Sakit, bahwa rumah sakit adalah fasilitas pelayanan kesehatan yang menyelenggarakan pelayanan kesehatan perorangan secara lengkap yang

7) Endang Wahyati Yustina, Mengenal Hukum Rumah Sakit. (Bandung: Keni Media, 2012), hal. 7.

8) Salim HS, Perkembangan Hukum Kontrak Innominat Di Indonesia. (Jakarta: Sinar Grafika, 2003), hal. 15. 
menyediakan pelayanan rawat inap, rawat jalan, dan gawat darurat serta yang lainnya.

Dengan demikian menurut Undang-undang No 44 Tahun 2009 tentang Rumah Sakit tugas utama rumah sakit adalah memberi pelayanan kesehatan perorangan secara paripurna. Pelayanan kesehatan di dalam perorangan adalah setiap hal kegiatan pelayanan kesehatan yang diberikan oleh tenaga kesehatan untuk merawat dan meningkatkan kesehatan, mencegah dan menyembuhkan penyakit serta memulihkan kesehatan.

Pelayanan kesehatan khususnya di rumah sakit pada umumnya, diawali dengan sebuah transaksi terapeutik atau perjanjian penyembuhan antara dokter dengan pasien. Oleh karena itu, pada awalnya hubungan hukum yang terjadi di rumah sakit adalah antara pasien dan dokter. Perjanjian penyembuhan yang oleh beberapa pakar hukum kesehatan sering disebut transaksi terapeutik, berasal dari kata transactie $e^{9)}$ yang artinya perjanjian dan therapeuticus yang artinya penyembuhan. Jadi transaksi terapeutik artinya perjanjian penyembuhan.

Perjanjian penyembuhan pada dasarnya tidak ada penafsiran jelas dari pembuat undang-undang. Hermien Hadiati Koeswadji menyebutkan yang dimaksud dengan transaksi terapeutik adalah transaksi untuk mencari atau menemukan terapi yang paling tepat oleh dokter untuk membuat pasien menjadi sembuh dan pulih seperti semula. ${ }^{10}$ ) Dokter seharusnya menggunakan segala ilmunya, kepandaian, keterampilan, dan pengalaman yang dimiliki serta harus bertindak secara hati-hati dan teliti. Dalam perikatan "ikhtiar" dokter sama sekali tidak memberi jaminan akan kesembuhan pasiennya.

Hal ini memang tidak mungkin mengingat banyaknya variasi yang terdapat dalam diri pasien, misalnya: sifat dan macam penyakit, usia, komplikasi, taraf tingkat penyakit yang berbeda, dan hal-hal yang meliputi

\footnotetext{
${ }^{9)}$ Hermien Hadiati Koeswadji, Hukum Kedokteran. (Bandung: Citra Aditya Bakti, 1998), hal. 13.

${ }^{10)}$ Hermien Hadiati Koeswadji, Hukum Kedokteran (Studi Tentang Hubungan Hukum Dalam Mana Dokter Sebagai Salah Satu Pihak), (Bandung: Citra Aditya, 1998), hal. 26.
} 
daya tahan tubuh. ${ }^{11)}$ Dalam doktrin kesehatan hukum tanggung jawab rumah sakit tersebut di atas dikenal dengan ajaran vicarious liability atau respondeat superior, yang artinya tanggung jawab dalam pelayanan medik tidak hanya difokuskan pada tenaga medis atau nonmedisnya saja melainkan telah diperluas pada tanggung jawab rumah sakit. Teori ini yang selanjutnya dikenal corporate liability for all malpractice committed within hospital walls. ${ }^{12)}$

Purwahid Patrik menyebutkan bahwa tanggung jawab tersebut identik dengan tanggung gugat secara kualitatif. Artinya rumah sakit bertanggung jawab tanpa ada kesalahan atau dapat dikatakan tanggung gugat risiko (risico aansprakelijkheid) sebagai lawan dari tanggung gugat berdasarkan kesalahan. $^{13)}$

Rumah sakit yang besar biasa disebut Medical Center (pusat kesehatan), biasanya melayani seluruh pengobatan modern dengan teknologi yang cangih. Hampir secara keseluruhan rumah sakit di Indonesia juga telah membuka pelayanan kesehatan tanpa menginap atau biasa di sebut rawat jalan bagi masyarakat umum. Sering kali beberapa klinik atau poliklinik di dalam suatu rumah sakit. Rumah sakit juga memiliki akreditasi di mana suatu upaya peningkatan mutu pelayanan rumah sakit. ${ }^{14)}$

Dalam rumah sakit juga terdapat dokter di dalamnya, "Dokter" adalah seorang tenaga ahli untuk kesehatan yang menjadi tempat di mana terjadi kontak pertama pasien dengan dokternya untuk selesaikan semua masalah dalam kesehatan yang dihadapi tidak memandang jenis penyakit baik dalam , golongan usia, dan jenis kelamin. Sedini dan sedapat mungkin, secara menyeluruh, dan dalam koordinasi serta kolaborasi dengan profesional kesehatan lainnya, dengan digunakannya prinsip pelayanan

${ }^{11)}$ Guwandi, Hukum Medik, (Jakarta: Fakultas Kedokteran Universitas Indonesia, 2007), hal. 18.

12) Guwandi, A Concise Glossary Of Medical Law Terms Landmark Decisions. (Jakarta: Fakultas Kedokteran Universitas Indonesia, 2007), hal.20.

13) Purwahid Patrik, Perkembangan Tanggung Gugat Resiko Dalam Perbuatan Melawan Hukum. (Semarang 5 Mei, 1990), hal. 13.

14 ) Sutoto, Panduan Penyusunan Dokumen Akreditasi, Cetakan Ke-1. (Jakarta: Komisi Akreditasi Rumah Sakit, 2012), hal. 5. 
yang efektif serta efisien dan tanggung jawab sangat profesional, hukum, etika dan moral.

Kewajiban umum untuk seorang dokter yaitu untuk menjunjung tinggi serta menghayati dan melakukan sumpah, seorang dokter dan juga harus selalu siap melakukan profesinya menurut ukuran yang tinggi dan, juga dalam melakukan pekerjaan seorang dokter tidak boleh dilandasi oleh pertimbangan keuntungan pribadi. ${ }^{15)}$

Rumah sakit tidak boleh membeda-bedakan pasien karena dalam Undang-Undang No 44 Tahun 2009 tentang Rumah Sakit Pasal 29 yaitu mengenai kewajiban rumah sakit adalah memberi pelayanan kesehatan yang aman, bermutu, anti diskriminasi serta efektif dengan mendahulukan kepentingan pasien sesuai dengan standar pelayanan rumah sakit. kenyataanya ada sebuah rumah sakit yang melanggar ketentuan undangundang tersebut rumah sakit ini berlokasi di Jakarta.

Rumah sakit ini bernama rumah sakit Mitra Keluarga. Dalam kasusnya rumah sakit tersebut menolak pasien seorang anak kecil bernama Debora yang menderita infeksi paru. Pasien ditolak karena orang tua pasien belum bisa membayar uang muka ruang pediatric intensive care unit (PICU) di mana ruang tersebut dikhususkan untuk balita karena ruangannya hangat.Tetapi karena orang tua pasien tidak bisa membayar langsung pada saat itu maka ditolak lah pasien tersebut.

Bahkan pihak orang tua Debora memberikan jaminan berupa Badan Penyelengara Jaminan Sosial (BPJS) tapi tetap ditolak oleh pihak rumah sakit dan karena hal tersebut Debora tidak bisa mendapatkan perawatan secara khusus sehingga mengakibatkan pada hari yang sama Debora meninggal dikarenakan ditolak oleh pihak rumah sakit tersebut. Padahal berdasarkan Undang-Undang No 8 Tahun 1999 tentang Perlindungan Konsumen (Selanjutnya akan disebut dengan UUPK), pasien tersebut

${ }^{15)}$ M.Jusuf Hafiah dan Amri Amir, Etika Kedokteran dan Hukum Kesehatan Edisi 3. Cetakan Ke-1. (Fakultas Kedokteran USU: Kode Etik Kedokteran, 2004), hal. 15. 
termasuk konsumen yang harus di layani oleh penyedia jasa yaitu rumah sakit. $^{16)}$

Sebagai konsumen Debora harus dilayani sebaik mungkin oleh pihak rumah sakit. Kasus Debora ini juga ada yang dialami di daerah Bekasi dimana seorang pasien bernama Reny Wahyuni ditolak oleh tujuh rumah sakit di kota bekasi dan atas tindakan penolakan pasien tersebut Reny wahyuni melahirkan dengan kondisi anaknya meninggal dunia. Kasus Reny ini dikarenakan ditolak tujuh rumah sakit karena Reny memakai Badan Penyelengara Jaminan Sosial (BPJS) dan pihak rumah sakit menolak karena hal tersebut sehingga nyawa anak Reny yang berada di dalam kandungan tidak terselamatkan dikarenakan terlambatnya pertolongan medis. ${ }^{17)}$

Selain kasus Debora dan Reny hal serupa juga dialami oleh seorang yang bernama M. Rizki Akbar yaitu seorang anak berusia dua tahun menderita sakit jantung ditolak oleh enam rumah sakit dikarenakan rumah sakit menolak pelayanan Badan Penyelengara Jaminan Sosial (BPJS) dan karena keterlambatan penanganan medis tersebut mengakibatkan M. Rizki Akbar meninggal dunia. ${ }^{18)}$

Berdasarkan uraian di atas, maka untuk mendalami permasalahan tanggung jawab yang harus dilaukukan oleh pihak rumah sakit dimasukan dalam proposal ilmiah yang berjudul "Tanggung Jawab Rumah Sakit Mitra Keluarga Kali Deres Atas Tindakan Penolakan Pasien Yang Berujung Pada Kematian Ditinjau Dari Undang-undang No 8 Tahun 1999 Tentang Perlindungan Konsumen".

16) Kasus Debora, DPR Nilai RS Mitra Keluarga Sengaja Langgar Undang-Undang”, www.cnnindonesia.com, 13 September 2017, hal. 1.

17) Berita Satu," Ditolak 7 RS di Bekasi, Putri Reny Lahir dalam Kondisi Meninggal", www.beritasatu.com, 12 Juni 2017, hal. 1.

18) CNN, "Ragam Kasus Mirip Bayi Debora”, www.cnnindonesia.com, 12 September 2017, hal. 1 . 


\section{B. Permasalahan}

Berdasarkan uraian dari latar belakang tersebut, maka pemasalahan dirumuskan sebagai berikut:

Bagaimana tanggung jawab rumah sakit atas penolakan memberi pelayanan kesehatan kepada pasien yang berakibat pada kematian ditinjau dari Undang-undang Nomor 8 Tahun 1999 tentang Perlindungan Konsumen?

\section{Metode Penulisan}

1. Tipe Penelitian

Tipe penelitian yang akan digunakan Penulis dalam penelitian ini adalah penelitian yuridis normatif. Penelitian ini Penulis akan menganalisis permasalahan yang ada dengan peraturan perundangundangan yang berlaku untuk melihat bagaimana tanggung jawab rumah sakit terhadap konsumen.

\section{Jenis Bahan Hukum}

Penelitian ini penulis menggunakan bahan hukum. Jenis bahan hukum yang diperoleh dari hasil penelaahan keputusan atau penelaahan terhadap berbagai literatur atau bahan pustaka yang berkaitan dengan masalah atau materi penelitian yang sering disebut bahan hukum bahan hukum. ) yang penulis gunakan dalam penelitian ini adalah:

a. Bahan Hukum Primer

Bahan hukum primer yang terdiri atas Peraturan perundangundangan yurisprudensi atau putusan pengadilan dan perjanjian internasional (traktat). Penulis penggunaan bahan hukum primer berupa peraturan perundang-undangan antara lain: Undang-undang No 8 Tahun 1999 tentang Perlindungn Konsumen, Undang-undang No 44 Tahun 2009 tentang Rumah Sakit) dan Undang-undang No 36 tahun 2009 tentang Kesehatan.

b. Bahan Hukum Sekunder 
Bahan hukum sekunder, yaitu bahan hukum yang dapat memberikan penjelasan terhadap bahan hukum primer, yang dapat berupa rancangan perundang-undangan, hasil penelitian buku buku teks, jurnal ilmiah, surat kabar (Koran), pamphlet, lefleat, brosur, dan berita internet. )

\section{c. Bahan Non Hukum}

Bahan non hukum atau bahan yang bukan hukum juga dapat digunakan di dalam penelitian hukum. Bahan non hukum ini dapat membantu dalam melakukan penelitian hokum yang termasuk dalam bahan non hukum ini ialah buku-buku mengenai hal-hal di luar bidang hukum, kemudian wawancara juga termasuk dalam bahan non hukum.

Dalam teknik pengumpulan bahan hukum yang dimaksudkan untuk memperoleh bahan hukum dalam penelitian. Di dalam teknik pengumpulan bahan hukum yang mendukung dan berkaitan dengan pemaparan penelitian ini yaitu studi dokumen atau studi kepustakaan. Studi dokumen yaitu suatu alat untuk mengumpulkan bahan hukum yang dilakukan melalui bahan hukum tertulis dengan mengunakan content analisys.

Teknik ini berguna untuk mendapatkan suatu landasan teori dengan mengkaji serta mempelajari buku-buku, peraturan perundang-undangan, dokumen, laporan, arsip juga hasil penelitian lainnya baik cetak ataupun elektronik. Pengumpulan bahan hukum ini diawali dengan kegiatan inventarisasi, dengan pengoleksian serta pengorganisasian bahan hukum ke dalam suatu sistem informasi, sehingga dapat memudahkan kembali pencarian bahan hukum tersebut.

Bahan-bahan hukum tersebut dikumpulkan menjadi satu dengan studi dokumentasi, yaitu dengan melakukan suatu pencatatan terhadap sumber bahan hukum primer serta bahan hukum sekunder, selanjutnya dilakukan tindakan inventarisasi terhadap bahan hukum yang relevan dengan cara pencatatan atau juga pengutipan dengan menggunakan 
sistem kartu. Masing-masing kartu dikasih identitas dan sumber bahan hukum yang dikutip dan juga halaman dari sumber-sumber kutipan. selain itu, diklasifikasikan menurut sistematika rencana untuk tesis serta, sehingga ada kartu untuk bahan Bab I juga Bab II, dan selanjutnya, terkecuali untuk bagian penutup. lalu dilakukan kualifikasi fakta serta hukum.

Seterusnya akan dilakukan pencarian melalui kepustakaan yang berkaitan dengan fungsi notaris dalam melakukan tindakan menjamin keabsahan surat kuasa khusus bercap jempol yang berlaku di dalam pengadilan. Dalam hal melakukan penelitian ini, akan meneliti bahan hukum sekunder. Dengan demikian ada dua kegiatan utama yang dilakukan di dalam melaksanakan penelitian ini, yaitu adalah Library Research (studi kepustakaan) yang didapat dari kepustakaan, dengan melakukan mengkaji, menelaah serta mengolah literatur, peraturan undang-undang, artikel atau tulisan yang berkaitan dengan permasalahan yang akan diteliti.

3. Pendekatan

Dalam penelitian hukum ada berbagai macam pendekatan. Dengan melakukan pendekatan, dapat menemukan informasi dari berbagai macam aspek dan juga mengenai isu-isu yang akan dicari jawabnya. Pendekatan yang digunakan di dalam penelitian ini penulis juga menggunakan pendekatan-pendekatan Perundang-undangan (Statue Approach) Pendekatan perundang-undangan juga dilakukan dengan melihat semua perundang-undangan dan juga regulasi yang juga bersangkautan dengan isu-isu hukum yang sedang ditangani, dengan memakai Undang-undang No 8 Tahun 1999 Tentang Perlindungn Konsumen. Penulis juga menggunakan pendekatan konseptual (Conseptual Approach) yaitu suatu pendekatan yang beranjak dari doktrin-doktrin dan pandangan-pandangan yang berkembang dalam ilmu hukum.

4. Spesifikasi Penelitian 
Spesifikasi penelitian yang digunakan dalam penelitian ini bersifat deskriptif analitis, yaitu "untuk menemukan, menggambarkan secara menyeluruh, dan mengkaji norma-norma hukum positif". Penelitian deskriptif analitis difokuskan pada norma hukum primer seperti peraturan perundang-undangan No 36 tahun 2009 tentang Kesehatan, dan Undang-undang No 44 tahun 2009 tentang Rumah Sakit yang berkaitan dengan Undang-Undang No 8 tahun 1999 tentang Perlindungan Konsumen. Penelitian ini bersifat deskriptif karena Penelitian deskriptif adalah penelitian yang sederhana dan mudah dilakukan (tidak memerlukan pemahaman mengenai statistik yang terlalu dalam).

Penelitian deskriptif yang baik seharusnya juga memiliki proses dan dasar yang hampir sama dengan penelitian kuantitatif. Untuk dapat menggambarkan subjek dalam hal penelitian yang jelas pada saat melakukan penelitian, maka diperlukan suatu ketelitian dalam melakukan sebuah tindakan.

\section{Teknik Analisis Bahan Hukum}

Menurut Peter Mahmud Marzuki dalam mengutip pendapatnya Philipus M.Hadjon memperlihatkan metode deduksi silogisme yang juga diajarkan oleh Aristoteles. Dalam penggunaan suatu metode deduksi berpangkal dari premis mayor yang artinya pernyataan yang bersifat umum. Lalu diajukan premis minor yaitu bersifat khusus, dari kedua premis tersebut kemudian ditarik kesimpulan di dalamnya atau conclusion. Tetapi dalam argumentasi dalam hukum, silogisme hukum tidak sesederhana seperti silogisme tradisional. Penelitian ini menggunakan suatu teknik analisis data juga logika deduktif dan, logika deduktif atau suatu hal pengolahan bahan-bahan hukum dengan cara deduktif yaitu suatu hal yang menjelaskan yang sifatnya umum dan menariknya menjadi suatu kesimpulan yang khusus.

Analisis suatu bahan-bahan hukum dalam melakukan penelitian ini dilakukan dengan teknik deskriptif, mendiskripsikan bahan dengan cara 
mengkonstruksikan hukum juga argumentasi, serta selanjutnya dilakukan penilaian berdasarkan pada suatu alasan yang sifatnya penalaran hukum, yaitu dengan mengemukakan suatu doktrin dan juga asas-asas yang ada kaitannya dengan suatu permasalahan.

\section{II.Pembahasan}

Rumah sakit merupakan sebuah institusi pelayanan kesehatan yang berfungsi untuk menyediakan dan menyelenggarakan upaya kesehatan yang bersifat penyembuhan dan pemulihan pasien dan keselamatan pasien. Pelayanan kesehatan yang diberikan oleh pihak rumah sakit kepada pasien juga dapat dipandang sebagai pelayanan yang diberikan antara pelaku usaha (Rumah Sakit) dengan pasien (Konsumen). ${ }^{38)}$

Penilaian konsumen pada kualitas pelayanan rumah sakit merupakan hal penting sebagai acuan dalam pembenahan pelayanan sehingga terciptanya suatu kepuasan pelangan dan menciptakan suatu loyalitas dari konsumen. ${ }^{39)}$ Pada saat ini penyelenggaraan pelayanan kesehatan di rumah sakit tidak sesederhana seperti pada zaman dahulu. Kebutuhan untuk mengelola rumah sakit dengan berbagai permodalan tidak dapat lagi dielakkan. Rumah sakit membutuhkan permodalan yang cukup terutama dengan makin banyaknya teknologi baru yang harus disediakan.

Tenaga yang cukup banyak juga menjadi kebutuhan pokok, sehingga membutuhkan pengorganisasian yang lebih professional dan tersedianya tenaga-tenaga teknis yang mahir untuk menangani alat-alat yang makin canggih. Oleh karena itu, dalam hal ini mau tidak mau akan mempengaruhi fungsi rumah sakit dalam penyelenggaraan pelayanan kesehatan.

Pada era saat ini rumah sakit memiliki suatu karakteristik dan juga memiliki organisasi yang kompleks dan paradigma yang sudah berubah. Rumah sakit tidak lagi seperti dulu yang dianggap kebal terhadap suatu bentuk gugatan-gugatan hukum, yang sebelumnya pada saat itu rumah sakit dianggap

${ }^{38)}$ Indra Bastian, Penyelesaian Sengketa Kesehatan, (Jakarta: Salemba Medika, 2011), hal. 5.

39) Tjiptono dan Chandra, Pemasaran Jasa. (Yogyakarta: Bayu Media Publishing, 2005), hal. 28. 
sebagai lembaga sosial yang kebal hukum berdasarkan doctrine of charitable immunity. Perubahan paradigma ini terjadi sejak adanya kasus Darling vs Charleston Community Memorial Hospital pada tahun $1965,{ }^{19)}$ manajemen modern, lengkap dengan manajemen risiko.

Rumah sakit tidak boleh membeda-bedakan pasien karena dalam UndangUndang No 44 Tahun 2009 tentang Rumah Sakit Pasal 29 yaitu mengenai kewajiban rumah sakit adalah memberi pelayanan kesehatan yang aman, bermutu, antidiskriminasi, juga efektif dengan mengutamakan kepentingan pasien sesuai dengan standar pelayanan rumah sakit. Kenyataannya ada sebuah rumah sakit yang melanggar ketentuan undang-undang tersebut rumah sakit ini berlokasi di Jakarta. Rumah sakit ini bernama rumah sakit Mitra Keluarga. Dalam kasusnya rumah sakit tersebut menolak pasien seorang anak kecil bernama Debora yang menderita infeksi paru. Pasien ditolak karena orang tua pasien belum bisa membayar uang muka ruang pediatric intensive care unit $(P I C U)$ di mana ruang tersebut dikhususkan untuk balita karena ruangannya hangat.Tetapi karena orang tua pasien tidak bisa membayar langsung pada saat itu maka ditolak lah pasien tersebut. Bahkan pihak orang tua Debora memberikan jaminan berupa Badan.

Penyelengara Jaminan Sosial (BPJS) tapi tetap ditolak oleh pihak rumah sakit dan karena hal tersebut Debora tidak bisa mendapatkan perawatan secara khusus sehingga mengakibatkan pada hari yang sama Debora meninggal dikarenakan ditolak oleh pihak rumah sakit tersebut. Padahal berdasarkan Undang-undang No 8 Tahun 1999 tentang Perlindungan Konsumen (Selanjutnya akan disebut dengan UUPK), pasien tersebut termasuk konsumen yang harus di layani oleh penyedia jasa yaitu rumah sakit. ${ }^{20)}$

Sebagai konsumen Debora harus dilayani sebaik mungkin oleh pihak rumah sakit. Kasus Debora ini juga ada yang dialami di daerah Bekasi dimana seorang pasien bernama Reny Wahyuni ditolak oleh tujuh rumah sakit di kota

${ }^{19)}$ Sofwan Dahlan, Malpraktik dan Tanggung Jawab Korporasi. (Bali: Kongres Nusa Dua Bali, 2014), hal. 1.

$20)$ Kasus Debora, DPR Nilai RS Mitra Keluarga Sengaja Langgar Undang-Undang”, www.cnnindonesia.com, 13 September 2017, hal. 1. 
bekasi dan atas tindakan penolakan pasien tersebut Reny wahyuni melahirkan dengan kondisi anaknya meninggal dunia. Kasus Reny ini dikarenakan ditolak tujuh rumah sakit karena Reny memakai Badan Penyelengara Jaminan Sosial (BPJS) dan pihak rumah sakit menolak karena hal tersebut sehingga nyawa anak Reny yang berada di dalam kandungan tidak terselamatkan dikarenakan terlambatnya pertolongan medis. ${ }^{21)}$

Selain kasus Debora dan Reny hal serupa juga dialami oleh seorang yang bernama M. Rizki Akbar yaitu seorang anak berusia dua tahun menderita sakit jantung ditolak oleh enam rumah sakit dikarenakan rumah sakit menolak pelayanan Badan Penyelengara Jaminan Sosial (BPJS) dan karena keterlambatan penanganan medis tersebut mengakibatkan M. Rizki Akbar meninggal dunia. ${ }^{22)}$

\section{A. Dasar Hukum Yang Mengatur Tanggung Jawab Rumah Sakit,}

Aturan hukum yang mengatur mengenai Rumah Sakit, pelayanan kesehatan dan pelayanan terhadap konsumen yaitu sudah ada dan hal ini diatur di dalam Undang-Undang di bawah ini :

1. Undang-Undang No 44 Tahun 2009, Tentang Rumah sakit,

Pasal 29 Ayat 1 huruf (e) dan (f) Undang-undang Nomor 44 tahun 2009 Tentang Rumah Sakit yang berisi :

(e). menyediakan sarana, dan pelayanan bagi masyarakat tidak mampu atau miskin;

(f). melaksanakan fungsi sosial antara lain dengan memberikan fasilitas pelayanan pasien tidak

Mampu atau miskin, pelayanan gawat darurat tanpa uang muka, ambulan gratis, pelayanan korban

21) Berita Satu," Ditolak 7 RS di Bekasi, Putri Reny Lahir dalam Kondisi Meninggal", www.beritasatu.com, 12 Juni 2017, hal. 1. hal. 1 .

22) CNN, "Ragam Kasus Mirip Bayi Debora", www.cnnindonesia.com, 12 September 2017, 
Bencana, dan kejadian luar biasa, atau bakti sosial bagi misi kemanusiaan;

menyediakan sarana dan pelayanan bagi masyarakat

Pasal 32, Undang-undang Nomor 44 Tahun 2009 Tentang Rumah

Sakit yang berisi :

Setiap pasien mempunyai hak:

a. memperoleh informasi mengenai tata tertib dan peraturan yang berlaku di Rumah Sakit; 2. memperoleh informasi tentang hak dan kewajiban pasien; c.memperoleh layanan yang manusiawi, adil, jujur, dan tanpa diskriminasi; 3. memperoleh layanan kesehatan yang bermutu sesuai dengan standar profesi dan standar prosedur operasional; 4. memperoleh layanan yang efektif dan efisien sehingga pasien terhindar dari kerugian fisik dan materi; 5. mengajukan pengaduan atas kualitas pelayanan yang didapatkan; 6. memilih dokter dan kelas perawatan sesuai dengan keinginannya dan peraturan yang berlaku di Rumah Sakit 7. meminta konsultasi tentang penyakit yang dideritanya kepada dokter lain yang mempunyai Surat Izin Praktik (SIP) baik di dalam maupun di luar Rumah Sakit; 8. mendapatkan privasi dan kerahasiaan penyakit yang diderita termasuk data-data medisnya; 9. mendapat informasi yang meliputi diagnosis dan tata cara tindakan medis, tujuan tindakan medis, alternatif tindakan, risiko dan komplikasi yang mungkin terjadi, dan prognosis terhadap tindakan yang dilakukan serta perkiraan biaya pengobatan; 10. memberikan persetujuan atau menolak atas tindakan yang akan dilakukan oleh tenaga kesehatan terhadap penyakit yang dideritanya; 11. didampingi keluarganya dalam keadaan kritis; 12. menjalankan ibadah sesuai agama atau kepercayaan yang dianutnya selama hal itu tidak mengganggu pasien lainnya; 13. memperoleh keamanan dan keselamatan dirinya selama dalam perawatan di Rumah Sakit; 14. mengajukan usul, saran, perbaikan atas perlakuan Rumah Sakit terhadap dirinya; 15. 
menolak pelayanan bimbingan rohani yang tidak sesuai dengan agama dan kepercayaan yang dianutnya; 16. menggugat dan/atau menuntut Rumah Sakit apabila Rumah Sakit diduga memberikan pelayanan yang tidak sesuai dengan standar baik secara perdata ataupun pidana; dan 17. mengeluhkan pelayanan Rumah Sakit yang tidak sesuai dengan standar pelayanan melalui media cetak dan elektronik sesuai dengan ketentuan peraturan perundangundangan.

1) Undang-undang Republik Indonesia Nomor 8 Tahun 1999 Tentang Perlindungan Konsumen. Pasal 7 huruf $\mathrm{C}$ yang berisi pelaku usaha berkewajiban untuk memperlakukan atau melayani konsumen secara benar dan jujur serta tidak diskriminatif.

2) Undang-undang Republik Indonesia Nomor 36 Tahun 2009 Tentang Kesehatan. Pasal 190 yang berisi :

b. Pimpinan fasilitas pelayanan kesehatan dan/atau tenaga kesehatan yang melakukan praktik atau pekerjaan pada fasilitas pelayanan kesehatan yang dengan sengaja tidak memberikan pertolongan pertama terhadap pasien yang dalam keadaan gawat darurat sebagaimana dimaksud dalam Pasal 32 ayat (2) atau Pasal 85 ayat (2) dipidana dengan pidana penjara paling lama 2 (dua) tahun dan denda paling banyak Rp200.000.000,00 (dua ratus juta rupiah).

c. Dalam hal perbuatan sebagaimana dimaksud pada ayat (1) mengakibatkan terjadinya kecacatan atau kematian, pimpinan fasilitas pelayanan kesehatan dan/atau tenaga kesehatan tersebut dipidana dengan pidana penjara paling lama 10 (sepuluh) tahun dan denda paling banyak Rp1.000.000.000,00 (satu miliar rupiah).

YLKI melihat dari beberapa sudut kalau kita lihat dari UUPK konsumen telah menjadi korban diskriminasi. Karena dilihat juga dari sisi undang-undang kesehatan mempunyai fungsi sosial jika hanya karena 
belum bisa membayar uang muka kepada pihak rumah sakit itu jelas dapat dikatakan diskriminasi dan dalam kondisinya hal ini harus dilakukan segera berbeda dengan orang membeli makanan dengan uang sedikit dapat sedikit makanannya.

Saran YLKI untuk Rumah Sakit Mitra Keluarga yaitu Rumah Sakit harus patuh pada undang-undang dan SOP yang berlaku dan tidak bertentangan dengan apa yang ada karena dikhawatirkan bisa saja sopnya melanggar ketentuan undang-undang dan saran ini berlaku disetiap Rumah Sakit bukan hanya Rumah Sakit Mitra Keluarga saja tetapi rumah sakit yang lain semua perlu diperiksa dan diperbaiki kembali pelayananpelayanannya. Agar tidak terjadi lagi kasus seperti ini.

Dengan demikian dapat disimpulkan bahwa Rumah Sakit telah melakukan tindakan yang kurang maksimal terhap pelayanan kepada pasien karena atas tindakan tersebut pasien meninggal. Rumah Sakit memang sudah melakukan tindakan darurat. Akan tetapi Rumah Sakit belum maksimal.

Atas tindakannya karena pasien tidak bisa membayar uang muka yang telah ditetapkan oleh Pihak Rumah Sakit. Tetapi hal yang dilakukan pihak rumah sakit telah salah karena menyalahi aturan ketentuan undang-undang yang berlaku.

Kesimpulannya adalah karena dilihat berdasarkan Undang-undang baik di lihat dari UUPK, Undang-undang Kesehatan dan Undang-undang Rumahsakit bahwa tindakan yang dilakukan oleh pihak rumah sakit melanggar ketentuan Undang-undang tersebut maka pihak Rumah Sakit wajib bertanggung jawab atas tindakan yang merugikan pasien tersebut.

Tanggung jawab yang pantas ditanggung oleh pihak Rumah Sakit adalah berupa ganti rugi berupa uang dengan jumlah yang pantas untuk diberikan kepada pihak keluarga korban yaotu keluarga bayi Debora.

Sedangkan dalam hal ini tidak bisa seperti itu karena hal ini berkaitan dengan kesehatan dan dalam hal ini YLKI berpendapat bahwa Rumah Sakit Mitra Keluarga Kalideres telah melakukan tindakan diskriminasi dan 
unsur diskriminasinya itu ada keharusan, keangkuhan, tidak ada daya tawar disaat konsumen sangat membutuhkan itu dan terlebih lagi undangundang kesehatan mengharuskan Rumah Sakit berfungsi social.

Penulis juga melakukan wawancara dan ini adalah hasil wawan cara. Dimana penulis mewawancarai YLKI, Dr.susanti Adhi Nugroho dan dr. Ronaldo Simamora.

Kalau untuk sanksi YLKI melihat dari undang-undang itu sendiri ada sanksi pidana atau perdata kalau perdata. Hal ini perlu adanya ganti rugi terhadap korban dan bisa juga selain ganti rugi dikenakan sanksi administratif yang memutuskan itu adalah pengadilan tetapi sebagai eksekusinya adalah pihak Dinas Kesehatan. Sedangkan dalam undangundang perlindungan konsumen itu terkait pasal 19 tentang ganti rugi juga terkait pidana.

Sedangkan menurut hasil wawan cara oleh pihak Ibu susanti Menurut Ibu Susanti rumah sakit tidak boleh mengutamakan pembayaran karena kesehatan pasien yang utama dan tidak boleh membeda-bedakan pasien.

Kasus ini Rumah Sakit dapat dikenakan sanksi dan bukan hanya rumah sakit. Tetapi dokter juga bisa terkena sanksi bahkan saat ini banyak dokter yang mengasuransikan dirinya karena banyak tuntutan tuntutan terhadap malpraktek kedokteran.

Menurut Ibu Susanti sanksi yang harus dikenakan pada Rumah Sakit yaitu sanksi ganti rugi berupa uang. Karena kecerobohan dari rumah sakit dan dokter tersebut. Juga terdapat unsur malpraktek dari rumah sakit tersebut dan malpraktek ada banyak ada yang tidak diurus dengan baik dan ada juga kesalahan dalam melakukan praktek.

Selanjutnya menurut Ibu Susanti sanksi administratif berupa pemberhentian sementara menurut beliau tidak pernah terjadi. Karena Rumah Sakit dibutuhkan masyarakat sehingga itu bukan kesalahan Rumah Sakit melainkan kesalahan dari oknum rumah sakit atau kesalahan dokter bisa juga sehingga rumah sakit tidak bisa dihentikan. Tidak sepantasnya 
dan belum pernahoperasional Rumah Sakit diberhentikan karena kesalahan seperti itu tidak ada misalkan izin dicabut itu tidak bisa.

Dan selanjutnya tanggapan dari dr.Ronaldo Simamora

Menurut dokter Ronal Rumah Sakit Mitra Keluarga pastinya sudah melakukan tindakan berdasarkan pasal 29 ayat 1 huruf e dan F tentang rumah sakit karena untuk sekarang ini Rumah Sakit diwajibkan menggunakan bantuan kegiatan seperti BPJS. Akan tetapi untuk masalah bantuan tersebut sebatas mana bantuannya itu belum tahu karena itu tergantung dari SOP rumah sakit masing-masing.

Menurut dokter ronal tanggung jawab yang harus dilakukan Rumah Sakit adalah dimana rumah sakit berkewajiban menangani atau melakukan tindak lanjut untuk tindakan emergency untuk saving Life. contohnya ketika pasien di rumah sakit datang ke IGD ketika dia membutuhkan pertolongan pertama contohnya memberi alat bantu nafas yang dilakukan segera itu harus dilakukan Rumah Sakit sesegera mungkin sehingga tindak lanjut apa yang diambil oleh dokter dan Rumah Sakit tersebut itu akan segera ditindaklanjuti oleh pasien yang membutuhkannya. Jadi pasien itu sehingga dapat ditangani sesuai indikasi dan juga sesuai dengan apa yang diperlukan pada tindakan emergency pasien.

Untuk sanksi administratif menurut dokter Ronal tidak diharus dilakukan. Tetapi ketika sudah diputuskan oleh pihak pemerintah melalui Dinas Kesehatan setempat memutuskan untuk melakukan pemberhentian sementara izin rumah sakit ini sebagai bertujuan sebagai untuk koreksi agar dimana rumah sakit lebih siap melayani pasien sesegera mungkin dalam mengambil keputusan untuk mencegah kejadian berikutnya tidak terjadi lagi dan bertujuan untuk memberi kelonggaran berupa administratif kepada pasien yang benar-benar membutuhkan pertolongan tindakan lebih lanjut lagi.

Menurut dokter Ronal dokter yang menangani pasien ini sudah melakukan tindakan dengan benar dan sebaik mungkin terhadap pasien 
dan dokter Ronal percaya bahwa dokter yang menangani pasien Debora ini sudah melakukan tindakan saving life.

Dokter Ronal juga berpendapat tanggung jawab ini sebenarnya lebih pantas diberikan kepada rumah sakit walaupun secara structural diatur oleh direksi. Tetapi yang bertanggung jawab atas kasus ini lebih dibebankan kepada rumah sakitnya.

Rumah Sakit telah dapat dikatakan melanggar ketentuan pasal 7 huruf c UUPK tentang perlindungan konsumen. Secara pelayanan sudah benar akan tetapi yang menjadi permasalahannya dalam administratifnya karena pasien tidak mampu membayar. Karena ini Rumah Sakit pun tidak bisa memberikan pelayanan yang sesuai dengan ketentuan pasal 7 huruf c UUPK.

Saran dari dokter Ronal yaitu pasien tetap dating ke IGD dan di situ nanti pasien mendapatkan tindakan Saving Life dan jika di rumah sakit tidak memadai peralatan atau ada kendala lain. Maka sebaiknya Rumah Sakit merujuk pasien ke rumah sakit lain agar pasien mendapatkan pelayanan yang seharusnya dibutuhkan.

\section{Penutup}

\section{A. Kesimpulan}

Setelah melakukan penelitian sesuai dengan rumusan masalah, maka Penulis memperoleh kesimpulan :

Rumah sakit seharusnya memberikan ganti rugi berupa uang yang sesuai dengan kesalahan yang dilakukan oleh pihak rumah sakit dan ganti rugi ini berdasarkan UUPK. Ganti rugi dalam UUPK ini sebagai bagian dari sanksi administratif dan pidana.

Jika pihak rumah sakit tidak memberikan gani rugi maka dikenakan sanksi pidana, hal ini dalam UUPK diatur pasal 60 dan pasal 62, di dalam pasal 60 terdapat sanksi administratif yaitu ganti rugi sebesar paling banyak Rp 200.000.000,00 (dua ratus juta rupiah). 
Sedangkan jika rumahsakit dikenakan sanksi pidana, dalam UUPK diatur dalam pasal 62 dipidana dengan pidana penjara paling lama 5 (lima) tahun atau pidana denda paling banyak Rp 2.000.000.000,00 (dua miliar rupiah).

Pelaku usaha yang melanggar akan di penjara paling lama 2 (dua) tahun atau pidana denda paling banyak Rp 500.000.000,00 (lima ratus juta rupiah).

Sedangkan dalam Undang-Undang Kesehatan, sanksi ini di atur dalam pasal 190 dimana pimpinan fasilitas pelayanan kesehatan dan/atau tenaga kesehatan yang melakukan praktik atau pekerjaan pada fasilitas pelayanan kesehatan yang dengan sengaja tidak memberikan pertolongan pertama terhadap pasien yang dalam keadaan gawat darurat akan dipidana dengan pidana penjara paling lama 2 (dua) tahun dan denda paling banyak Rp200.000.000,00 (dua ratus juta rupiah).

Dalam hal perbuatan sebagaimana dimaksud di atas mengakibatkan terjadinya kecacatan atau kematian, pimpinan fasilitas pelayanan kesehatan dan/atau tenaga kesehatan tersebut dipidana dengan pidana penjara paling lama 10 (sepuluh) tahun dan denda paling banyak Rp1.000.000.000,00 (satu miliar rupiah).

Dalam penjelasan Undang-Undang tentang Kesehatan dijelaskan bahwa jika pihak rumah sakit tidak memberikan pelayanan kesehatan dan mengakibatkan kematian maka pihak pimpinan fasilitas Rumah Sakit dapat dikenakan pidana penjara paling lama 10 (sepuluh) tahun dan denda paling banyak Rp1.000.000.000,00 (satu miliar rupiah).

Sedangkan dalam Undang-Undang Rumah Sakit tidak diatur mengenai sanksi dalam kasus berdasarkan rumusan masalah maka dari itu sanksi ini di atur oleh UUPK dan Undang-Undang Kesehatan.

\section{B. Saran}

Ada beberapa saran yang dapat disampaikan berdasarkan hasil penelitian ini, yaitu : 


\section{Daftar Pustaka}

\section{A. BUKU}

Abdulkadir Muhammad, Hukum Perusahaan Indonesia, (Bandung: Citra Aditya Bakti, 2010).

Azrul Azwar, Pengantar Administrasi Kesehatan, (Jakarta: Binarupa Aksara, 2004).

Boy Subirosa Sabarguna, Bangunan Rumah Sakit. (Jakarta: Salemba Medika, 2011).

(Jakarta: Salemba Medika, 2011).

Endang Wahyati Yustina, Mengenal Hukum Rumah Sakit. (Bandung: Keni Media, 2012).

Guwandi, A Concise Glossary Of Medical Law Terms Landmark Decisions. (Jakarta: Fakultas Kedokteran Universitas Indonesia, 2007).

Hukum Medik, (Jakarta: Fakultas Kedokteran Universitas Indonesia, 2007).

Hermien Hadiati Koeswadji, Hukum Kedokteran. (Bandung: Citra Aditya Bakti, 1998).

. Hukum Kedokteran (Studi Tentang Hubungan

Hukum Dalam Mana Dokter Sebagai Salah Satu Pihak), (Bandung: Citra Aditya, 1998).

Indrati S. Maria Farida, Ilmu Perundang-undangan2 Proses dan Teknik Pembentukannya. Penerbit : (Yogyakarta: Kansius, 2007).

Indra Bastian, Penyelesaian Sengketa Kesehatan, (Jakarta: Salemba Medika, 2011).

Miru, Ahamadi dan Sutarman Yodo. Hukum Perlindungan Konsumen. (Jakarta: PT. Raja Grafindo Persada, 2004). dan Yodo Sutarman, Hukum Perlindungan Konsumen,

(Jakarta, Raja Gratindo Persada 2008).

M.Jusuf Hafiah dan Amri Amir, Etika Kedokteran dan Hukum Kesehatan Edisi 3. Cetakan Ke-1. (Fakultas Kedokteran USU: Kode Etik Kedokteran, 2004).

Peter Mahmud Marzuki, Pnelitian Hukum, Edisi 1 cetakan ke-2, (Jakarta: Kencana Prenada Media Group, 2006). . Penelitian Hukum, Cetakan Ke-4. (Jakarta:

Kencana Prenada Media Group, 2005). Pengantar Ilmu Hukum, Cetakan ke-9, (Jakarta:

Kencana, 2016).

Purwahid Patrik, Perkembangan Tanggung Gugat Resiko Dalam Perbuatan Melawan Hukum. (Semarang 5 Mei, 1990).

Satjipto Raharjo, Ilmu Hukum, (Bandung: PT. Citra Aditya Bakti, 2000). 
Salim HS, Perkembangan Hukum Kontrak Innominat Di Indonesia. (Jakarta: Sinar Grafika, 2003).

Siahaan N.H.T, Hukum Konsumen Perlindungan Konsumen Dan Tanggung Jawab Produk, (Jakarta, Pantai Rei, 2005).

Sofwan Dahlan, Malpraktik dan Tanggung Jawab Korporasi. (Bali: Kongres Nusa Dua Bali, 2014).

Sulastomo, Manajemen Kesehatan. (Jakarta: PT Gramedia Pustaka Utama, 2007).

Sutoto, Panduan Penyusunan Dokumen Akreditasi, Cetakan Ke-1. (Jakarta: Komisi Akreditasi Rumah Sakit, 2012).

Tjiptono dan Chandra, Pemasaran Jasa. (Yogyakarta: Bayu Media Publishing, 2005).

Veronica Komalawati, Hukum dan Etika Praktek Dokter, Cetakan Ke-1. (Jakarta: Sinar Harapan, 1989).

\section{B. PERATURAN PERUNDANG-UNDANGAN}

Indonesia. Undang-undang Nomor 8 Tahun 1999 tentang Perlindungan Konsumen (Lembaran Negara Republik Indonesia Nomor 22 Tahun 1999).

. Undang-undang Nomor 36 Tahun 2009 tentang. Kesehatan (Lembaran Negara Republik Indonesia. Tahun 2009 Nomor 144).

Pasal 1 Angka 7. . Undang-undang Nomor 44 Tahun 2009 tentang Rumah. Sakit (Lembaran Negara Republik Indonesia Tahun 2009.

\section{WAWANCARA}

Andre Scondery, Wawancara, Abdul Basith dari bidang pengaduan hukum dan pelayanan Medic Yayasan Lembaga Konsumen Indonesia, Rabu 18 Juli 2018.

Andre Scondery, Wawancara, dengan Susanti Adi Nugroho, Dosesn Hukum Perlindungan Konsumen Fakultas Hukum Universitas Tarumanagara, Senin 30 Juli 2018.

Andre Scondery, Wawancara, dengan dr.Ronaldo Simamora Dokter Rumah Sakit Harapan Kita Jakarta Barat, Senin 30 Juli 2018.

\section{INTERNET}

Kasus Debora, DPR Nilai RS Mitra Keluarga Sengaja Langgar UndangUndang", www.cnnindonesia.com, 13 September 2017.

Berita Satu," Ditolak 7 RS di Bekasi, Putri Reny Lahir dalam Kondisi Meninggal", www.beritasatu.com, 12 Juni 2017.

CNN, "Ragam Kasus Mirip Bayi Debora", www.cnnindonesia.com, 12 September 2017. 